\title{
The Effects of Online Learning during the Outbreak of Coronavirus Disease 2019 (COVID-19) towards Grade 10-12 Thai Students' Opinions
}

\author{
Suthee Khamkaew iD \\ Lecturer, English Language Teaching, Wat Phrasrimahadhat Secondary Demonstration School, Phranakhon Rajabhat University, \\ Thailand
}

Corresponding Author: Suthee Khamkaew, E-mail: ajansuthee@hotmail.com, ajansutheekhamkaew@gmail.com

ARTICLE INFORMATION ABSTRACT

Received: December 01, 2020

Accepted: January 06, 2021

Volume: 3

Issue: 1

DOI: 10.32996/jweep.2021.3.1.4

\section{KEYWORDS}

The Effects of Online Learning, Coronavirus Disease 2019 in Thailand, Grade 10-12 Thai Students

\begin{abstract}
This study aimed to study the effects of integrating online learning in schools during the outbreak of COVID-19 in Thailand from mid-March to July 2020. The participants were 508 students consisting of grade 10-12 levels from five different schools in each province of Thailand. The questionnaire employed via "Poll Feature Line Group" was separated into three categories; 1) The general informations of the students, 2) The advantages of online learning, and 3) The limitations of online learning. 508 students gave the feedback by checking the items of the questionnaires via "Poll Feature Line Group". The researchers took two weeks to complete the survey in October 2020. The results of the questionnaire were calculated into the statistical values in Percentage, Mean Range and Standard Deviation. The results revealed that the majority of the students studying online studied in grade 12 in science-mathematics program, and Thai and English subjects were primarily available online. The most three advantages were - 1) Online learning promotes the social distancing., 2) Online learning helps students save time and cut on expenses especially transport costs., and 3) Students can communicate via various platforms like Line, Email, Facebook, and Google Classroom. On the contrary, the most limitations were -1 ) Students have no chance to participate in extracurricular activities in school., 2) The mere presence of a smartphone reduces students' ability to focus on the lessons., and 3) It can be hard to find answers to questions or resolve difficulties, especially when discussion forum participation is low.
\end{abstract}

\section{Introduction}

The virus, which causes the respiratory infection Covid-19, was first detected in the city of Wuhan, China, in late 2019. The outbreak spread quickly across the globe in the first months of 2020 and declared a global pandemic by the WHO on 11 March (WHO, 2020). A pandemic is when an infectious disease is passing easily from person to person in many parts of the world at the same time. Governments across the world have been forced to limit public movement and close businesses and venues in a bid to slow the spread of the virus. This has had a devastating impact on the global economy and educational systems both in developed and developing countries (Xiang et al., 2020).

The COVID-19 pandemic quickly led to the closure of universities and colleges around the world with government instructions to follow social distancing that could help to flatten the infection curve and reduce total fatalities from the disease. The most important pandemic precaution called "social distancing" or "physical distancing" has attempted to reduce interpersonal contact and thereby minimize the kind of community transmission that could develop quickly in dense social networks like the university campus (Weeden and Cornwell, 2020).

The World Health Organization (WHO) warned that Covid-19 will spread rapidly in the coming months. Covid-19 is continuing its spread across the world with more than 85 million confirmed cases in 190 countries and nearly two million deaths on 4 January

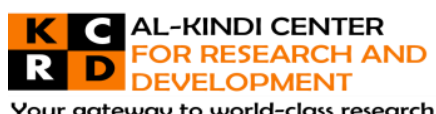

Your gateway to world-class research

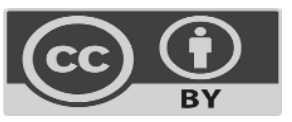

Published by Al-Kindi Center for Research and Development. Copyright (c) the author(s). This open access article is distributed under a Creative Commons Attribution (CC-BY) 4.0 license 
2021. Many countries have now approved vaccines for use but as populations await their roll-out, cases remain high across many parts of the world.

In Thailand, COVID-19 has led to the closing of schools as well. All schools have to deal with a crisis that requires the advanced technology to promote effective online learning in all levels. The Ministry of Education has launched the policy in how to satisfactorily deliver course content online, engage teachers and students and conduct suitable assessments. Therefore, COVID19 has boosted all schools to invest in online learning.

With school closures in Thailand extended until 1 July 2020, the Ministry of Education is launching new initiatives and building on previous work to enable students to continue their studies effectively and efficiently. In particular, Distance Learning Television (DLTV) and online learning are key pedagogical methods given physical distancing recommendations and the uncertainty of the COVID-19 pandemic.

According to the Ministry of Education, the new pedagogical approaches and parental role for teaching and learning during COVID-19 are:

Part I: For primary students (grade 1-6), the curricula will be different from that of older students. For this level, the pedagogical method will focus on one-way communication. In addition, there will be learning exercises and homework for learners to practice.

Part II: For secondary students (grade 7-12), it is necessary to ensure more interaction between students and teachers, hence the method will focus on a two-way communication approach. Apart from the DLTV method, teachers are expected to be more active in providing support to learners via different online platforms. By doing so, teachers can respond to different needs of learners, provide them with feedback and generate an exchange of ideas.

During the course of this pandemic period, parents or guardians will also have to adjust themselves and prepare to assume the role of teachers' assistants to help their children learn. The social distancing measures require people to stay home. Therefore, parents or guardians can spare time to assist teachers to push forward the Ministry's established mechanisms.

Moreover, almost teachers have been just a thumbnail on a Zoom conference call for the one month before July $1^{\text {st }}$ and in July because teachers concerned that students cannot complete the amount of the lessons in the time period. Therefore, they have taught online along with the normal schedule for two months as follows:

1. Wat Phrasrimahadhat Secondary Demonstration School, Phranakhon Rajabhat University, Bangkok which is an autonomous institution directly under the central administration of Phranakhon Rajabhat University was founded in 1953 with the primary goal of being as a laboratory for student teachers and providing the educational scheme for high school levels. The school offers an educational program that promotes a high standard of learning achievement from grade 7-12.

2. Sarawittaya School, Bangkok which is a large secondary school special type of coeducation under Bangkok Educational Service Area Office Area 2, the Ministry of Education. The school offered the educational scheme from grade 7-12 and five lesson plans in grade 10-12 - 1) Science - Mathematics, 2) Mathematics - English, and 3) English - foreign language such as Chinese, Japanese, French.

3. Wisutthikasattree School located in Samut Prakan Province provides the educational scheme from grade 7-12 and seven majors in grade 10-12; 1) Science - Mathematics (Gifted), 2) Science - Computer, 3) Home Economic, 4) English Japanese, 5) English - Chinese, 6) Thai - Social Studies, and 7) Fine Arts

4. Saint Joseph Nakhonsawan School which is in Nakhonsawan Province provides the educational scheme from nursery to grade 12. For senior high school, the school provides four majors; 1) Science - Mathematics, 2) Mathematics - English, 3) English - Chinese, and 4) Thai - Social Studies.

5. Angthong Pattamaroj Wittayakom School in Angtong Province offered the educational scheme from grade 7-12 and eight lesson plans in grade 10-12 - 1) Science - Mathematics, 2) The Genius Program I (Science - Mathematics), 3) The Genius Program II (Science - Technology), 4) The Genius Program (Science - Mathematics - Technology - Environment), 5) Japanese Chinese, 6) English - Mathematics, 7) General Arts, and 8) Mathematics - Political Science

6. Saparachinee Trang School situated in Trang Province provides the educational scheme from grade 7-12 and seven majors in grade 10-12 - 1) The Genius Program (Science - Mathematics - Technology - Environment: IPST), 2) The Genius Program (Science - Mathematics), 3) Science - Mathematics, 4) The Genius Program (Science - Mathematics - Computer: NoPaper), 5) English - Mathematics, 6) The Genius Program (Music - Thai Classical Dance), 7) English Program.

On July $1^{\text {st }}$, the reopening of schools is nationwide for all levels of public and private school in Thailand. Since mid-March, all schools in Thailand have been closed for classes as part of the government' efforts to battle COVID-19. After the lockdown, 1) 
Wat Phrasrimahadhat Secondary Demonstration School, Phranakhon Rajabhat University, Bangkok, 2) Sarawittaya School, Bangkok, 3) Wisutthikasattree School, Samut Prakan Province, 4) Saint Joseph Nakhonsawan School, Nakhonsawan Province, 5) Angthong Pattamaroj Wittayakom School in Angtong Province, and 6) Saparachinee Trang School, Trang Province started the new normal schedule. When students returned to their classes in school rooms, all school conducted an odd/even numbers system or day-off for each level. The students are given random numbers and the odd numbers come one day and the students with even numbers on another in order to keep social distancing among students in the classroom. As the results, the lessons are behind the schedule because students do not come to school as normal. At the start of August, when Thailand started easing restriction, teachers have spent the time continuing normal classes in school until the end of the $1^{\text {st }}$ semester.

With the urgent needs in use of online learning during COVID-19, it is necessary to assess their effectiveness with regards to teaching and learning from various stakeholders (Chauhan, 2017). This study aimed to study the effects of integrating online learning in schools during the outbreak of COVID-19 towards grade 10-12 students' opinions in Thailand from mid-March to July 2020. The questionnaire was employed via "Poll Feature Line Group". The study expected 1,000 participants studying in grade 10-12 students from five schools to answer the questionnaire. In addition, this study presented introduction, methods, finding and discussions, limitations of the study, and conclusion. Consequently, the findings will help identify the required changes on priority basis to make online learning more practical and worthwhile.

\section{Methods}

\subsection{The Participants}

Online learning encourage student-centered learning and they are easily manageable during this lockdown situation. It is worth considering that currently online learning is at a growing stage in Thailand. It started as emergency remote learning, and with further investments we can overcome any limitations. There is a need to train all teachers on the use of online modalities and developing lesson plan to increase interactivities. Focusing on online learning, the study was carried out to gather information in order to support the use of online learning in schools, considering their various advantages and limitations.

This study was aimed to report on research conducted at;

1) Wat Phrasrimahadhat Secondary Demonstration School, Phranakhon Rajabhat University, Bangkok,

2) Sarawittaya School, Bangkok,

3) Wisutthikasattree School, Samut Prakan Province,

4) Saint Joseph Nakhonsawan School, Nakhonsawan Province,

5) Angthong Pattamaroj Wittayakom School in Angtong Province, and

6) Saparachinee Trang School, Trang Province.

The researchers expected 200 participants who were grade 10-12 students and studied in various majors from each school to do the questionnaire.

The participants were 508 out of 1,000 students who studied online from mid-March to July 2020. The 492 participants did not do the questionnaire.

\subsection{Method of Data Collection}

To collect the data of the study, the questionnaire developing to explore students' opinions about the effects of online learning was applied. The questionnaire was developed and tried out in terms of advantages and limitations of online learning from some students who used to study online before the survey. The participants were students grade 10-12 accounting for 1,000 students in Academic Year of 1/2020 from different six schools. All participants gave the feedback by checking the items of the questionnaires via "Poll Feature Line Group". The researchers took two weeks to complete the survey in October 2020.

\subsection{Instruments of Data Collection}

The questionnaire was particularly employed for getting the data towards students' opinions about the effects of online learning. The purpose of the questionnaire of this study was to investigate the advantages and limitations of online learning. The questionnaire was also developed based on the preliminary interviews with some students who had experienced with online learning in July 2020, one month before the survey. The questionnaire was designed in Thai, and then translated into English. The Thai questionnaire was distributed via "Poll Feature Line Group" in order to minimize misunderstandings. The questionnaire was separated into three categories;

1) The general informations of the students consisted of 3 items,

2) The advantages of online learning consisted of 10 items, and

3) The limitations of online learning consisted of 12 items. 


\subsection{Method of Data Analysis}

The results and findings were presented in tables and figures together with full explanations. The results of the questionnaire were interpreted, categorized and tabulated on computer sheets and were calculated into the statistical values as follows:

(a) Percentage was applied to describe the general informations of the participants relating to their grade levels, school programs and subjects which offered the online learning.

(b) The data concerning the advantages and limitations of online learning during the COVID-19 were presented in Mean Range and Standard Deviation.

(c) A five-point Likert scale was used to score the levels of the satisfaction of students' opinions. It is a scale used in questionnaire to specify the level of agreement or disagreement:

\begin{tabular}{c|c|c}
\hline Scale & Agreement & Mean Range \\
\hline 5 & Strongly Agree & $4.50-5.00$ \\
4 & Agree & $3.50-4.49$ \\
3 & Neutral & $2.50-3.49$ \\
2 & Disagree & $1.50-2.49$ \\
1 & Strongly Disagree & $1.00-1.49$ \\
\hline
\end{tabular}

(d) Mean was used to interpret the average level of online learning towards the satisfaction of students' opinions. The higher mean score of each activity indicates higher satisfaction. On the other hand, the lower mean score indicates less satisfaction.

\section{Finding and Discussions}

The coronavirus COVID-19 outbreak disrupted people's life around the globe in 2020 and continued to rise through 2021. As in any other sector, the COVID-19 pandemic affected education in many ways especially teaching and learning methods. Government actions have followed a common goal of reducing the spread of coronavirus by introducing measures limiting social contact. Many countries suspended face-to-face teaching and exams (www.eacea.ec.europa.eu). Traditional classes are being replaced by various e-learning platforms which enable interaction between teachers and students. Moreover, in some circumstances, national television shows or social media platforms are being used for education. Some education systems announced exceptional holidays to better prepare for this distance-learning scenario.

In terms of the impact of the COVID-19 pandemic on different countries' education systems, many differences exist. This lack of homogeneity is caused by such factors as the start and end dates of academic years and the timing of school holidays. While some countries suspended in-person classes from March/April until further notice, others were less restrictive, and universities were only advised to reduce face-to-face teaching and replace it with online solutions wherever practicable. In other cases, depending on the academic calendar, it was possible to postpone the start of the summer semester (www.study.eu).

Fortunately, there is a range of modern tools available to face the challenge of distance learning imposed by the COVID-19 pandemic (Rodrigues et al., 2019). The modification of contents that were previously taught face-to-face is easily conceivable. There are however other important tasks in the learning process, such as assessment or autonomous learning, that can still be challenging without the direct supervision of teachers.

The study presented advantages and limitations to improve online learning during lockdown of schools because of COVID-19 pandemic. This study interprets viewpoints of 508 students from 1) Wat Phrasrimahadhat Secondary Demonstration School, Phranakhon Rajabhat University, Bangkok, 2) Sarawittaya School, Bangkok, 3) Wisutthikasattree School, Samut Prakan Province, 4) Saint Joseph Nakhonsawan School, Nakhonsawan Province, 5) Angthong Pattamaroj Wittayakom School in Angtong Province, and 6) Saparachinee Trang School, Trang Province. The results showed that online learning platforms were moderate source of teaching and learning during COVID-19 period and also caused many problems for them to learn as follows: 


\section{Figure 1: Grade Levels}

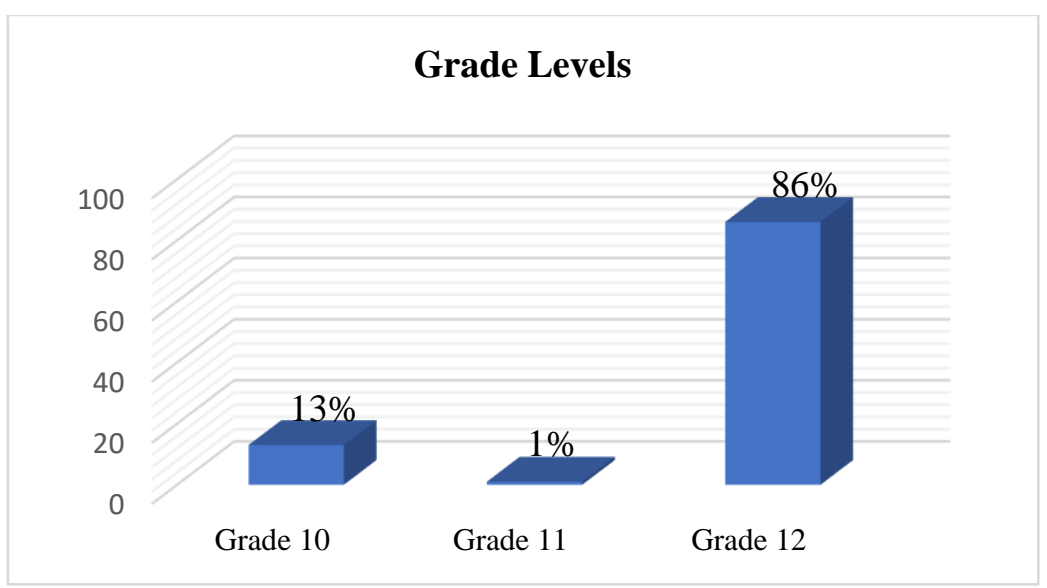

Figure 1 showed that the majority of the students ( $86 \%$ ) studied in grade 12 . This could be because all teachers worried that grade 12 students will not finish the lessons in time before they sit for TCAS examination. Since standardized educational tests are effective instruments administered to students to evaluate aptitude, abilities, knowledge, and capabilities (USNEl, 2008), different tests and assessment systems have been applied in different countries. Therefore, all teachers tried hard to launch out the lessons for grade 12 students because there are many indicators in Thai educational assessment, which are standardized measurements of varying levels of achievement, at every level of the Thai education system such as grade point average (GPAX), the ordinary national educational test (O-NET), General Aptitude Test (GAT), Professional Aptitude Test (PAT), 9 Common Subjects (Ministry of Education, 2013).

Figure 2: Programs

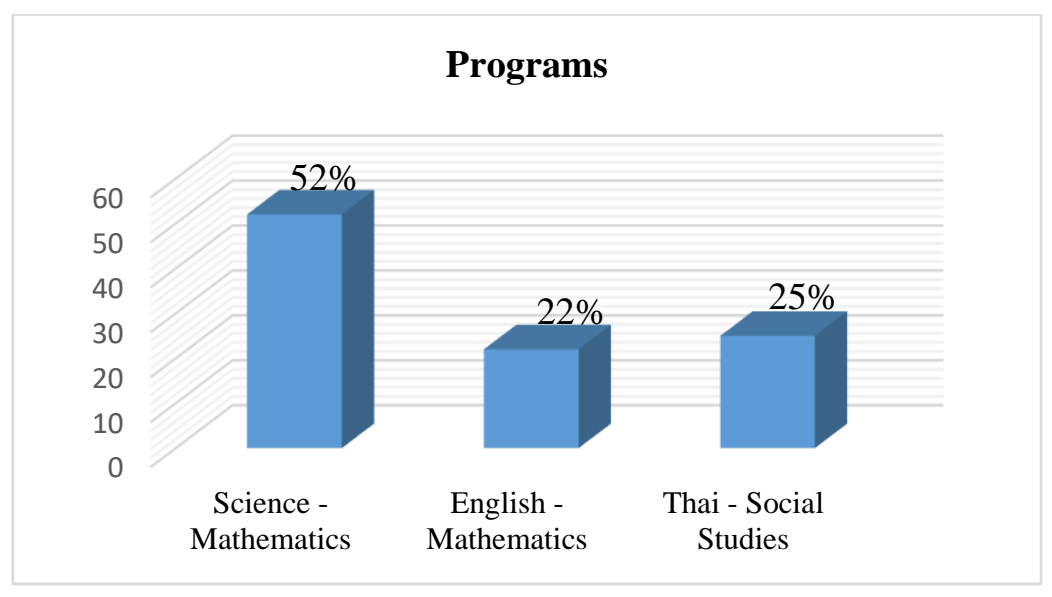

According to Figure 2, the results based on the questionnaire showed that most of the students ( $52 \%$ ) studying in sciencemathematics program. This might be because all schools mainly offer this program for high school students and many Thai parents expect their children studying in this program because this program could offer their children unlimited number of faculties in the university. 
Figure 3: Subjects

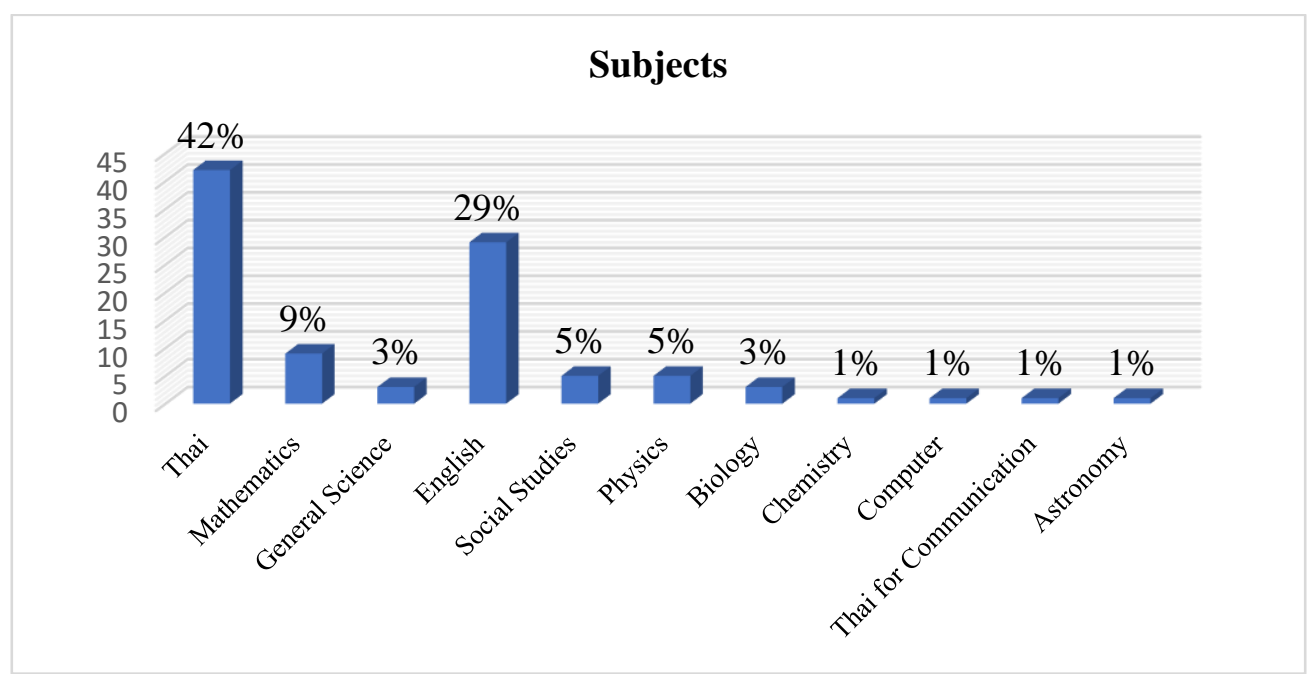

As shown in Figure 3, the majority of the subjects (42\%) were Thai subject, while $29 \%$ of them were English subject. The number of Thai subject and English subject were larger than that of other subjects; this could be because both Thai subject and English subject lay the important role in TCAS examination such as ONET, GAT-PAT and 9 common subjects.

Table 1: The Advantages for Online Learning during the Outbreak of COVID-19

Mean and Standard Deviation towards the Advantages of Online Learning ( $\mathrm{N}=508)$

\begin{tabular}{|c|c|c|c|}
\hline Criteria & Mean & S.D. & $\begin{array}{l}\text { Level of } \\
\text { Agreement }\end{array}$ \\
\hline $\begin{array}{l}\text { 1. With basically an Internet connection, students can attend the classes } \\
\text { wherever they are. }\end{array}$ & 4.52 & 0.42 & Strongly Agree \\
\hline $\begin{array}{l}\text { 2. With online learning, this helps students save time and cut on expenses } \\
\text { especially transport costs. }\end{array}$ & 4.54 & 0.45 & Strongly Agree \\
\hline $\begin{array}{l}\text { 3. Online learning allows students to learn even they get sick, as long as } \\
\text { they understand the contents. }\end{array}$ & 3.72 & 0.44 & Agree \\
\hline 4. There are not any problems with the attendance times. & 3.75 & 0.35 & Agree \\
\hline $\begin{array}{l}\text { 5. Students can care for their aging parents or ill parents along with } \\
\text { studies. }\end{array}$ & 3.81 & 0.39 & Agree \\
\hline $\begin{array}{l}\text { 6. Shy students may not have trouble approaching the instructor with } \\
\text { questions. }\end{array}$ & 3.72 & 0.31 & Agree \\
\hline $\begin{array}{l}\text { 7. Online learning increases the ability to search further information and } \\
\text { utilize the new technology for study. }\end{array}$ & 4.38 & 0.35 & Agree \\
\hline $\begin{array}{l}\text { 8. Students can communicate via various platforms like Line, Email, } \\
\text { Facebook, and Google Classroom. }\end{array}$ & 4.53 & 0.40 & Strongly Agree \\
\hline $\begin{array}{l}\text { 9. Learning from online platforms requires students to understand online } \\
\text { technology and make students to be computer literate. }\end{array}$ & 4.42 & 0.41 & Agree \\
\hline $\begin{array}{l}\text { 10. Online learning promotes the social distancing that effectively } \\
\text { prevents the spread of COVID-19. }\end{array}$ & 4.58 & 0.57 & Strongly Agree \\
\hline Total & 4.28 & 0.41 & Agree \\
\hline
\end{tabular}

The results were presented in the average number as follows:

Online learning is a flexible and effective source of teaching and learning as most of students agreed upon the fact that online learning helps in distant learning with easy administration and accessibility along with less use resource and time. From the survey, the average number of the advantages of online learning is agree (4.28). Since, online learning can be termed as a tool that can make the teaching-learning process more student-centered, more innovative, and even more flexible. Online learning is defined as learning experiences in synchronous or asynchronous environments using different devices (e.g., mobile phones, 
laptops, etc.) with internet access. In these environments, students can be anywhere (independent) to learn and interact with instructors and other students (Singh and Thurman, 2019).

The overall advantages of online learning is agree. The most four advantages of online learning which are strongly agree are - 1) Online learning promotes the social distancing that effectively prevents the spread of COVID-19 (4.58), 2) With online learning, this helps students save time and cut on expenses especially transport costs. (4.54), 3) Students can communicate via various platforms like Line, Email, Facebook, and Google Classroom. (4.53), and 4) With basically an Internet connection, students can attend the classes wherever they are. (4.52). As a result, it could be said that distance, scale, and personalized teaching and learning are the three biggest challenges for online teaching. Innovative solutions by institutions can only help us deal with this COVID-19 pandemic (Liguori and Winkler, 2020).

Furthermore, the most three advantages of online learning which are agree are -1 ) Learning from online platforms requires students to understand online technology and make students to be computer literate. (4.42), 2) Online learning increases the ability to search further information and utilize the new technology for study. (4.38), and 3) Students can care for their aging parents or ill parents along with studies. (3.81). This results directly related to Cojocariu et al. (2014) study that most of the terms (online learning, open learning, web-based learning, computer-mediated learning, blended learning, m-learning, for ex.) have in common the ability to use a computer connected to a network, that offers the possibility to learn from anywhere, anytime, in any rhythm, with any means

Table 2: The Limitations for Online Learning during the Outbreak of COVID-19

Mean and Standard Deviation towards the Limitations of Online Learning $(\mathrm{N}=508)$

\begin{tabular}{|c|c|c|c|}
\hline Criteria & Mean & S.D. & $\begin{array}{c}\text { Level of } \\
\text { Agreement }\end{array}$ \\
\hline $\begin{array}{l}\text { 1. It is quite one way communication that can cause the difficulties of } \\
\text { teaching and learning. }\end{array}$ & 3.71 & 0.42 & Agree \\
\hline $\begin{array}{l}\text { 2. It can be hard to find answers to questions or resolve difficulties, } \\
\text { especially when discussion forum participation is low. }\end{array}$ & 3.79 & 0.46 & Agree \\
\hline $\begin{array}{l}\text { 3. The mere presence of a smartphone reduces students' ability to focus } \\
\text { on the lessons. }\end{array}$ & 3.89 & 0.51 & Agree \\
\hline 4. Teachers lose control of their classes. & 3.62 & 0.44 & Agree \\
\hline $\begin{array}{l}\text { 5. Online learning cannot offer classroom interaction such as how to make } \\
\text { friends, be patient, get rid of disappointment, and especially to compete } \\
\text { the tasks. }\end{array}$ & 3.67 & 0.47 & Agree \\
\hline $\begin{array}{l}\text { 6. Teachers hardly check student understanding while the lesson's still } \\
\text { going on. }\end{array}$ & 3.71 & 0.45 & Agree \\
\hline 7. Students need more effective self-motivation. & 3.68 & 0.43 & Agree \\
\hline $\begin{array}{l}\text { 8. Students have no chance to participate in extracurricular } \\
\text { activities in school. }\end{array}$ & 4.53 & 0.50 & Strongly Agree \\
\hline $\begin{array}{l}\text { 9. Many students are unable to possess tablets, computers and } \\
\text { smartphones to participate in educational activities. }\end{array}$ & 3.51 & 0.36 & Agree \\
\hline $\begin{array}{l}\text { 10. Spending an extended amount of time for online learning can have } \\
\text { negative physical effects including muscle and joint injuries, increased } \\
\text { mortality rate associated with excessive sitting, and eyestrain from } \\
\text { computer use and associated symptoms. }\end{array}$ & 3.59 & 0.42 & Agree \\
\hline $\begin{array}{l}\text { 11. Parents have no time to take care of their children during online } \\
\text { learning. }\end{array}$ & 3.55 & 0.35 & Agree \\
\hline $\begin{array}{l}\text { 12. Students might have to incur some initial and hidden expenses like } \\
\text { installing a computer, getting a reliable Internet connection, and buying } \\
\text { additional resources such as a printer, a web camera and so forth. }\end{array}$ & 3.53 & 0.41 & Agree \\
\hline Total & 3.79 & 0.43 & Agree \\
\hline
\end{tabular}

The results were presented in the average number as follows:

Accessibility, affordability, flexibility, learning pedagogy, life-long learning, and policy are some of the arguments related to online pedagogy. It is said that online learning is easily accessible and can even reach to rural and remote areas. It is considered to be a relatively cheaper mode of education in terms of the lower cost of transportation, accommodation, and the overall cost 
of institution-based learning. Flexibility is another interesting aspect of online learning; a learner can schedule or plan their time. During this deadly virus spread such online platforms are needed where (a) video conferencing with at least 40 to 50 students is possible, (b) discussions with students can be done to keep classes organic, (c) internet connections are good, (d) lectures are accessible in mobile phones also and not just laptops, (e) possibility of watching already recorded lectures, and (f) instant feedback from students can be achieved and assignments can be taken (Basilaia et al., 2020).

Although online learning is beneficial in education system during the spread of COVID-19, the average number of the limitations of online learning is agree (3.79). The overall advantages of online learning is agree since it is commonly recognized that sometime student finds online teaching to be boring and unengaging. Online learning has so much of time and flexibility that students never find time to do it. Personal attention is also a huge issue facing online learning. Students want two-way interaction which sometimes gets difficult to implement. The learning process cannot reach its full potential until students practice what they learn. Sometimes, online content is all theoretical and does not let students practice and learn effectively. Students feel that lack of community, technical problems, and difficulties in understanding instructional goals are the major barriers for online learning (Song et al., 2004).

The most limitation of online learning is students have no chance to participate in extracurricular activities in school. (4.53). Moreover, the most three limitations of online learning which students rated agree are - 1) The mere presence of a smartphone reduces students' ability to focus on the lessons. (3.89), 2) It can be hard to find answers to questions or resolve difficulties, especially when discussion forum participation is low. (3.79), and 3) It is quite one way communication that can cause the difficulties of teaching and learning and teachers hardly check student understanding while the lesson's still going on. (3.71). This results parallel with Favale et al. (2020) as online learning has certain weaknesses in the form that it can hamper the communication between the learner and the teacher, that is, direct communication and human touch are lost. Moreover, student's non-serious behavior in terms of time and flexibility can cause a lot of problems. All students are not the same, they vary in degrees of their capabilities and confidence level. Some do not feel comfortable while learning online, leading to increased frustration and confusion. Inadequate compatibility between the design of the technology and component of psychology required by the learning process; and inadequate customization of learning processes can obstruct the teaching process and creates an imbalance.

\section{Limitations of the Study}

The COVID-19 has made schools to go from offline mode to online mode of pedagogy. This catastrophe will show us the beneficial side of online teaching and learning. Therefore, the quality enhancement of online teaching-learning is crucial at this stage. Online education in Thai schools has increased exponentially after the Covid-19 outbreak. During this tough time, the concern is not about whether online teaching-learning methods can provide quality education, it is rather how academic institutions will be able to adopt online learning in such a massive manner (Carey, 2020).

As the study participants belonged to 1) Wat Phrasrimahadhat Secondary Demonstration School, Phranakhon Rajabhat University, Bangkok, 2) Sarawittaya School, Bangkok, 3) Wisutthikasattree School, Samut Prakan Province, 4) Saint Joseph Nakhonsawan School, Nakhonsawan Province, 5) Angthong Pattamaroj Wittayakom School in Angtong Province, and 6) Saparachinee Trang School, Trang Province, the limitations are as follows:

1. Since all participants were required to answer the questionnaire via "Poll Feature Line Group", some did not intend to do it. How to persuade all participants to take apart in the survey was initially essential in order to get more accurate information for the study.

2. The study was performed on a relatively small population. It limits our ability to generalize the data from million students in Thailand. Consequently, a large scale survey is needed that would guarantee a fair representation of the target population of all students. For generalizability, a survey based on our findings should be conducted across the province or country in all levels of educational scheme.

\section{Further Study}

In response to significant demand, many online learning platforms are offering since the COVID-19 pandemic has utterly disrupted an education system. According to Wang and Hu (2019), online learning is a better alternative for the learners, and the researchers should be able to look for ways of making it more focused on thinking and creation. It should be understood that most online courses are dictated by technology (Donitsa-Schmidt and Topaz, 2018; Garcia and Badia, 2017). 
While some believe that the unplanned and rapid move to online learning with no training and insufficient preparation will result in a poor user experience that is unconducive to sustained growth, others believe that a new hybrid model of education will emerge, with significant benefits. Therefore, the integration of information technology in education will be further accelerated and that online education will eventually become an integral component of school education. As the limitations mentioned above, the further study should overcome and discover the evidence that learning online can be more effective in a number of ways as follows:

1. Online learning is expected to grow sharply. Future research should be concerned about an in-depth analysis of the practices that should be adopted such as online instruction practices, implementation process, and a course design to facilitate the improvement of methods of teaching and learning.

2. Online learning is continuing to grow, and more institutions are expected to offer online courses. The research should look at the number of students enrolling for the online studies for an instant the primary, high school, undergraduate, graduate, and doctorate levels.

3. The study should aim to get the view and perspectives of the students whether e-learning has actualized the academic goals for them.

4. With the enhancement of tools, the further study needs to find out the benefits of technological devices in the promotion of a highly efficient and effective social interaction and the expansion of a learning environment. The study needs to find out ways of making use of video conferencing, social networks and virtual reality environment that significantly enhance the e-learning process.

\section{Conclusion}

This study aimed to study the effects of integrating online learning in schools during the outbreak of COVID-19 in Thailand from mid-March to July 2020. School closures related to the COVID-19 pandemic have impacted hundreds of schools and affected millions of students. Schools, colleges, and universities in Thailand were closed when COVID-19 struck but lessons didn't stop when innovative educators turned to remote learning technologies. Through the crisis, millions of students across Thailand have been learning and studying using new collaborative digital tools and resources on a massive scale.

The COVID-19 that we are experiencing today will pass, leaving its devastating effects on the lives of thousands of people, ruining the economy and educational systems. The current study supports the use of online learning in school, considering its various advantages. Online learning encourage student-centered learning and they are easily manageable during this lockdown situation. It is worth considering that currently online learning is at a nascent stage in Thailand. It started as 'emergency remote learning', and with further investments we can overcome any limitations. There is a need to train faculty on the use of online modalities and developing lesson plan with reduced cognitive load and increased interactivities.

The findings of this study are considered to be of great importance to various stakeholders for several reasons. This study will help uncover critical areas and contribute to local literature on the subject, which in turn could be used by relevant authorities in improving their education initiatives. Lecturers may realize the importance of undertaking studies in information technology and online modes as a means of up-skilling their teaching abilities. The finding of this study will rebound to the benefit of schools by providing them important insights into ICT integrated teaching enabling them to strengthen their programs to better prepare lecturers to deal with the diverse exigencies of the COVID-19 pandemic.

In a similar vein, it will also present important information to Education authorities about the benefits of ICT integrated learning enabling them to include them as pedagogical reforms in education. In particular, they may have to revisit their curriculum so that ICT knowledge is included in their text at primary and secondary levels. This adaptation would better prepare the students for ICT integrated pedagogy at schools. Subsequently, the recommendations of the study will allow schools to create an interactive and enjoyable learning environment for all students amidst the nationwide lockdown due to COVID-19 pandemic. Learning environments are diverse platforms such as Google Meet, where users engage and interact to learn new skills. While learners can learn in an array of settings, the term refers to the more preferred and accurate alternative to the traditional classroom (Affouneh et al., 2020).

Eventually, a key lesson learned during the pandemic is the important role teachers play in ensuring that learning continues. As schools reopen, a lot will depend on teachers to ensure that children will be able to continue their education in a safe and healthy environment; and make up for knowledge and skills that may have been lost. 


\section{References}

[1] Affouneh, S., Salha, S., N., and Khlaif, Z. (2020). Designing Quality E-learning Environments Emergency Remote Teaching in Coronavirus Crisis. Interdisciplinary Journal of Virtual Learning in Medical Sciences, 11(2), 1-3.

[2] Basilaia, G., Dgebuadze, M., Kantaria, M., and Chokhonelidze, G. (2020). Replacing the classic learning form at universities as an immediate response to the COVID-19 virus infection in Georgia. International Journal for Research in Applied Science \& Engineering Technology, 8 (III).

[3] Carey, K. (2020). Is everybody ready for the big migration to online college? Actually, no. The New York Times. https://www.nytimes.com

[4] Chauhan, S. 2017. "A Meta-analysis of the Impact of Technology on Learning Effectiveness of Elementary Students." Computers and Education 105: 14-30.

[5] Cojocariu, V.-M., Lazar, I., Nedeff, V., and Lazar, G. (2014). SWOT Analysis of E-learning Educational Services from the Perspective of their Beneficiaries. Procedia-Social and Behavioral Sciences, 116, 1999-2003.

[6] Donitsa-Schmidt, S., and Topaz, B. (2018). Massive open online courses as a knowledge base for teachers. Journal of Education for Teaching, 44(5), 608-620. https://doi.org/10.1080/02607476.2018.1516350

Favale, T., Soro, F., Trevisan, M., Drago, I., and Mellia, M. (2020). Campus traffic and e-Learning during COVID-19 pandemic. Computer Networks, 176, 107290. https://www.eacea.ec.europa.eu/national-policies/eurydice/content/how-covid-19-affecting-

[8] schools-europe_en

[9] https://www.study.eu/article/impact-of-covid-19-on-studying-abroad-in-europe-overview https://www.who.int/dg/speeches/detail/whodirector-general-s-opening-remarks-at-the-mediabriefing-on-covid-19---11-march-2020.

[10] Liguori, E. W., and Winkler, C. (2020). From offline to online: Challenges and opportunities for entrepreneurship education following the COVID-19 pandemic. Entrepreneurship Education and Pedagogy. https://doi.org/10.1177/2515127420916738

[11] Ministry of Education (2013). Thai education system: Thai school level. Retrieved from http://www.moe.go.th/moe/th/home

[12] Rodrigues H, Almeida F, Figueiredo V, Lopes SL. (2019). Tracking e-learning through published papers: A systematic review. Computers and Education. 136; 87-98.

[13] Singh, V., and Thurman, A. (2019). How many ways can we define online learning? A systematic literature review of definitions of online learning (1988-2018). American Journal of Distance Education, 33(4), 289-306.

[14] Song, L., Singleton, E. S., Hill, J. R., and Koh, M. H. (2004). Improving online learning: Student perceptions of useful and challenging characteristics. The Internet and Higher Education, 7(1), 59-70. Chauhan, S. 2017. "A Meta-analysis of the Impact of Technology on Learning Effectiveness of Elementary Students." Computers and Education 105: 14-30.

[15] USNEI. (2008). Structure of the U.S. Education System. International Affairs Office, U.S. Department of Education. Retrieved from http://www.ed.gov/international/usnei/edlite-index.html

[16] Wang, H., Pi, Z., and Hu, W. (2019). The instructor's gaze guidance in video lectures improves learning. Journal of Computer Assisted Learning, 35(1), 42-50. https://doi.org/10.1111/jcal.12309

[17] Weeden, K. A., Benjamin, C. (2020). The small-world network of college classes: implications for epidemic spread on a university campus. Sociological Science, 7, 222-241.

[18] WHO (2020, March 11). WHO Director-General's opening remarks at the media briefing on COVID-19-11 March 2020. World Health Organization, March 11, 2020.

[19] Xiang, Y. T., Li, W., Zhang, Q., Jin, Y., Rao, W. W., Zeng, L. N., (2020). Timely research papers about COVID-19 in China. The Lancet. doi: https://doi.org/10.1016/S0140-6736(20)30375-5. 